\title{
NAFTA Liberalization and the Role of Nontariff Barriers
}

\author{
DAVID ROLAND-HOLST, KENNETH A. REINERT, \\ and CLINTON R. SHIELLS
}

\begin{abstract}
Tariff protection between the North American economies is relatively low by world standards, having declined significantly with the NAFTA accords. Despite this apparent move toward a more liberal trade regime, however, nontariff barriers and other deterrents still exert a pervasive influence on trade. In this paper, a calibrated general equilibrium model is used to evaluate the opportunity cost of trade reducing nontariff barriers. Our results indicate that the United States, Canada, and Mexico could realize substantial gains from a more comprehensive approach to trade liberalization but that the process of adjustment to full liberalization differs in important ways from adjustment to simple tariff removal.
\end{abstract}

\section{INTRODUCTION}

The North American Free Trade Agreement (NAFTA) is representative of a worldwide trend toward regionalism in trade negotiations. This shift away from multilateralism is a result of both the strengths and weaknesses of the GATT framework. On the one hand, GATT has been quite successful at demonstrating once and for all that relatively low nominal protection can greatly expand global trade opportunities. At the same time, however, these norms have lowered the stakes for regionalists, who can now remove residual protection with their neighbors secure in the knowledge that severe retaliation is not individually rational for other trading partners. The success of the GATT in reducing average nominal protection has also narrowed the negotiating agenda down to its more stubborn elements, such as food security and other agricultural policies.

The GATT's weaknesses have also become more apparent and problematic over time. In its early days, the multilateral negotiating framework faced a relatively easy task, with a few dominant economies leading the way and leveling nominal barriers on a lion's share of international tradc. Now, the family of influential traders is much larger, their geographic

David Roland-Holst - OECD Development Centre, 94 ruc Chardon-Lagache, 75016 Paris, France. Kenneth A. Reinert - Kalamazoo College, 1200 Academy Street, Kalamazoo, MI 49006 . Clinton R. Shiells • International Monetary Fund, 700 19th Street NW, Washington, DC 20431.

The opinions expressed here are those of the authors and should not be attributed to their affiliated institutions This work was completed before Shiells joined the IMF.

North American Journal of Economics \& Finance 5(2):137-168 Copyright $\odot 1994$ by JAI Press, Inc. ISSN 1062-9408

All rights of reproduction in any form reserved 
and economic interests are more diverse, and consensus is more difficult to achieve or even approximate. Finally, an emphasis in the multilateral negotiations on nominal protection has led to proliferation of nontariff trade control measures which in many instances threaten to reverse the long-term trend toward a more liberalized global trading regime. A prominent example of this is the Multifiber Arrangement governing textilc and apparcl tradc.

As it is currently under negotiation, the NAFTA is a partial response to the shortcomings each country might perceive in the Uruguay Round. Its full promise, in terms of regional economic efficiency and expanded trade, is unlikely to be realized, however, unless the removal of nontariff barriers is also negotiated. Empirical evidence presented below indicates that North American trade is significantly impeded by barriers of this type. Unilateral liberalization of tariffs, particularly on the part of Mexico, and the earlier bilateral pact with Canada have already stimulated continental trade and initiated extensive structural adjustments. ${ }^{1}$ Only complete liberalization can realize the economic potential of the North American economy, but a very different adjustment process may ensue from the simultaneous removal of nontariff barriers to regional trade.

With these considerations in mind, this paper examines the potential impact of a fuller NAFTA agenda with a calibrated general equilibrium (CGE) model. The model is calibrated to a three-country social accounting matrix (SAM) which details 26 sectors of production and is estimated for 1988. Detailed estimates on nominal import protection and nontariff barriers were also developed to compare the effects of partial and full libcralization. Our results indicate that all three countries stand to gain substantially at either stage in the reduction of trade barriers. It is apparent, however, that the pattern of adjustment in domestic production, factor use, demand, and trade in all three countries differs significantly between partial and complete liberalization. This means that current negotiations can only partially fulfill the stated objectives of greater economic efficiency and gains from trade. More seriously, the negotiating framework for nominal liberalization may provide very imperfect guidance toward the domestic and international issues governing the larger agenda of complete liberalization.

The next section, provides an overview of domestic economic structure and trade relations between the three countries. With this in mind, the third section surveys the current evidence on North American trade barriers. The fourth section discusses the structure and conventions of the CGE model, followed in section five by the simulation results obtained from it. A sixth and final section presents concluding remarks.

\section{THE STRUCTURE OF NORTH AMERICAN PRODUCTION, DEMAND, AND INCOME}

Our model is calibrated to a detailed three-country social accounting matrix (SAM) for Canada, the United States, and Mexico, estimated for the year 1988. This North American SAM and its construction are described in greater detail in Reinert, Roland-Holst, and Shiells (1993). The first step in its construction was to transform the macro accounts of the three countries into a North American macroeconomic SAM. This was done using data from Statistics Canada (March 1991 and April 1991), Reinert and Roland-Holst (1992), and Estados Unidos Mexicanos (1990). Trilateral trade flows were taken from U.S. Department of Commerce (1988), Globerman and Bader (1991), and U.S. International Trade Commission (1991). Factor service and capital flows were taken from U.S. Department of Commerce (1991). 
The second stage in the construction of the North American SAM was estimation of detailed sectoral accounts, including value added, domestic final demand, import, export, and interindustry transactions. Each of these were estimated for 26 production sectors. For value added, this was done using 1988 Canadian input-output accounts from Statistics Canada, 1988 U.S. data from Reinert and Roland-Holst (1992), and 1988 and 1985 Mexican data from Estados Unidos Mexicanos (1990) and Sobarzo (1991), respectively. For Canada, domestic final demand was taken from the 1988 Canadian input-output accounts. For the United States, sectoral domestic final demands were taken directly from Reinert and Roland-Holst (1992). For Mexico, sectoral domestic final demands were estimated based on 1985 shares from Sobarzo (1991).

Sectoral trade flows were estimated with SITC trade data from the United Nations, while domestic sectoral flows were estimated from individual country sources. Canadian interindustry flows for 1988 were rebalanced slightly to row and column controls calculated from the new sectoral data using the RAS procedure. ${ }^{2}$ U.S. interindustry flows were taken directly from Reinert and Roland-Holst (1992). Mexican interindustry flows from Sobarzo (1991) were updated from 1985 using row and column controls calculated from the estimated 1988 sectoral and a simple algebraic RAS procedure.

While the structure detailed in the $90 \times 90$ three-country SAM is the essential information set for the CGE model, it is too large to be readily interpreted by inspection. In Tables 1-3, we summarize the information from the SAM in a more accessible format. This information on the general structure of production, demand, income, and trade in each country will facilitate understanding of the simulation results reported later in this paper.

Table 1 presents structural information on the United States. For each of the 26 sectors and three aggregate sectoral categories (Primary, Manufacturing, and Services), the baseyear data for shares of gross outpul (column 1), value added (2), demand (3), exports (4), and imports (5) are given. These columns provide a snapshot of the sectoral composition of production, income, supply, demand, and trade in the United States. Services obviously dominate the production side of this economy, generating $63 \%$ of gross output and $77 \%$ of total value added. Manufacturing's share of gross output $(31 \%)$ far exceeds its value added share $(19 \%)$ because of its higher degree of intermediate use. Demand includes imports, and these raise the overall share of Manufactures while lowering that of Services. U.S. exports are also concentrated in Agriculture (9\%) and Manufacturing (63\%), and Imports are even more Manufacture dependent $(71 \%)$.

Column 6 lists the ratios of labor to capital value added in percentage terms, and these vary widely across sectors. Agriculture has a weighted average of $56 \%$ labor to capital value added, while Manufacturing spends nearly twice as much on labor as capital, and Services two-and-a-half times as much. Ferrous metals (sector 14) are dominated by returns to labor, which get over ten times the value added accruing to capital in $1988 .{ }^{3}$ Value added ratios in Services vary widely, from lows of $42 \%$ and $43 \%$ in the capital-intensive Electricity and Finance sectors to over $600 \%$ in Construction.

Columns 7 and 8 present measures of overall trade dependence, exports in gross output and imports in total demand, respectively. Generally speaking, average sectoral import dependence is greater than export dependence in 1988. The U.S. economy exports only 5\% of gross output overall, but imports $13 \%$ of total demand. The most export-intensive sectors in the current aggregation are Mining (18\%), Transport Equipment (17\%), Iron and Steel (16\%), and Chemicals (15\%). Together, these sectors account for $28 \%$ of exports (column 4). The most import-dependent sectors are Leather Goods (67\%), Other Manufactures 


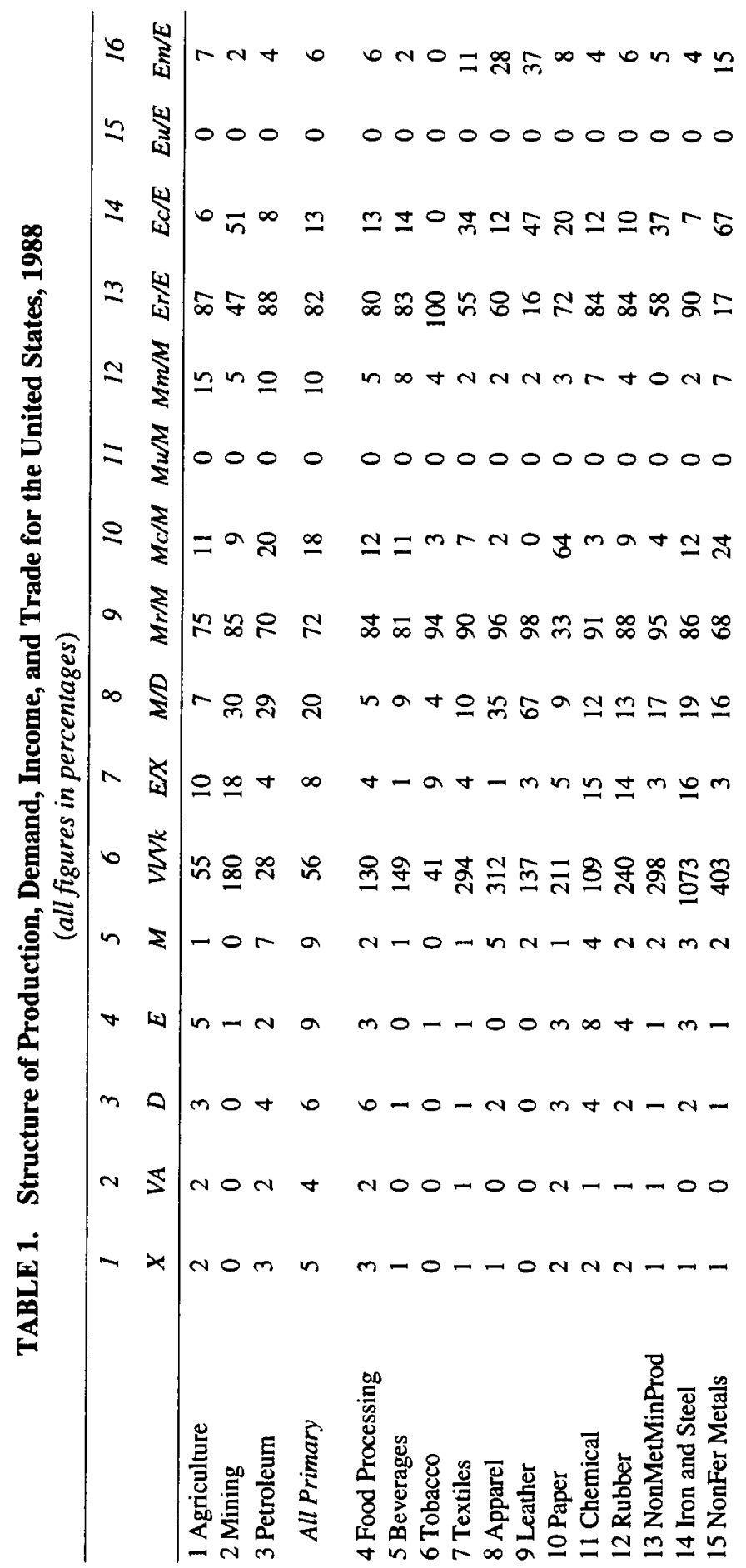




\begin{tabular}{|c|c|c|c|c|}
\hline $0 \pm=m n$ & $r$ & 000000 & 0 & $n$ \\
\hline 00000 & 0 & 000000 & 0 & 0 \\
\hline N $¥ m \stackrel{m}{\sharp}$ & 出 & 000000 & 0 & $\mathscr{0}$ \\
\hline ธே゚゚ッ & 8 & 888888 & 8 & 2 \\
\hline $0 \sim \infty+m$ & $n$ & 000000 & 0 & $\theta$ \\
\hline 00000 & 0 & 000000 & 0 & 0 \\
\hline$n=n g r$ & 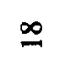 & 000000 & 0 & $\because$ \\
\hline 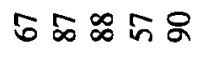 & $\stackrel{2}{\infty}$ & $\circ 8 \circ 888$ & 8 & $\bar{\infty}$ \\
\hline mম্লm & ్ㅗ & 0 이잉 & + & $\underline{2}$ \\
\hline$n \pm m=\infty$ & 이 & $00+04-$ & $n$ & $n$ \\
\hline 㑒을 空志志 & 욤 & 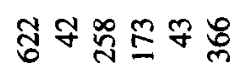 & b & 导 \\
\hline$\nabla \sigma \equiv \cong r$ & $F$ & $0=00 \mathrm{~m}-$ & 요 & 8 \\
\hline$m o=0 n$ & $\hat{0}$ & $00 \geqslant 000$ & $\stackrel{\sim}{\sim}$ & 8 \\
\hline $\tan a r$ & o & $a+r+a n$ & 字 & 8 \\
\hline$N-m N-$ & 2 & $n \forall m 00 m$ & 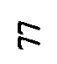 & 8 \\
\hline$m n+n$. & $\vec{m}$ & $r+\Xi n \pm d$ & 3 & 8 \\
\hline 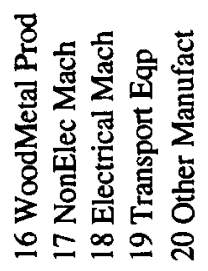 & 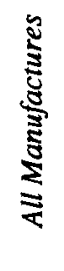 & 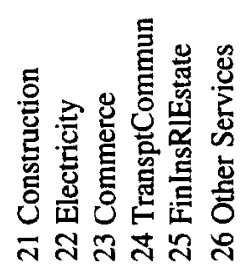 & 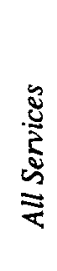 & 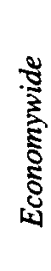 \\
\hline
\end{tabular}


(39\%), Apparel (35\%), and Electrical Machinery (33\%), together accounting for $31 \%$ of all imports (column 5).

The last eight columns of Table 1 contain import (9-12) and export (13-16) shares for each trading partner in total imports or exports. ${ }^{4}$ It is apparent from columns 9 and 13 that the United States relies for most of its import supply and export demand upon markets outside of North America, with and economy-wide average of $81 \%$ for imports and $79 \%$ for exports. Thus, the potential for trade diversion in response to the NAFTA may be considerable. The United States and Canada do maintain the world's largest bilateral trade relationship, however (United States-Japan is second), and U.S. trade shares with respect to its northern neighbor are in many sectors significant. About two-thirds (64\%) of U.S. Paper imports and $39 \%$ of Transport Equipment imports come from Canada. Canada, in turn, buys two-thirds of U.S. NonFerrous Metal product exports, over half (51\%) of its Mining exports, and over one-third of its exports of Leather (47\%), NonElectric Machinery (41\%), Transport Equipment (38\%), NonMetal Mineral Products (37\%), and Textiles (34\%). Generally speaking, the United States had significantly higher export dependence on Canada than import dependence under 1988 protection patterns.

U.S. trade dependence on Mexico is generally lower, as would be expected given the relative magnitude of the three economies. Import dependence averages only $10 \%$ in primary sectors and 5\% in manufactures (column 12) but is as high as $15 \%$ in Agriculture and $8 \%$ in beverages. As an export market, Mexico is more attractive to some U.S. sectors (column 16 ), although the averages for primary and manufacturing are only $6 \%$ and $7 \%$, respectively. U.S. Leather producers direct $37 \%$ of their exports to Mexico and $28 \%$ of U.S. Apparel exports were destined there in 1988. The lower economy-wide averages for U.S.-Mexico trade shares indicate that considerable scope may exist for trade creation within, and diversion to, a North American customs union.

Table 2 presents comparable structural information for Canada, and close inspection reveals interesting contrasts with its main trading partner. Canada's economy is more concentrated in Primary $(8 \%)$ and Manufacturing (38\%) than the United States, with significantly greater relative shares for Mining, Paper, and Transport Equipment and less concentration on Service sector activities. The value added distribution also reflects this but is again skewed toward services. Canadian demand exhibits similar compositional differences, and exports are even more Primary and Manufacturing dependent. Canada has 50\% more export concentration (14\%) than the United States, three-quarters (73\%) of its exports are Manufactures, and it has less than half the Service export concentration (13\%) of the United States.

The ratio of labor to capital value added in Canada varies significantly from comparable sectors in the United States. In many cases (e.g., Mining, Petroleum, and Construction), this may be due to differing products or technologies, but the differences here are generally greater than one might reasonably expect from these sources alone. ${ }^{5}$ Broad sectoral and economy-wide averages are more similar, but labor still receives substantially more in Canadian Primary and Manufacturing sectors, less in Services.

Generally, Canada appears to be about twice as trade dependent as the United States, with $13 \%$ of output going to exports and $25 \%$ of demand met by imports. Moreover, over half of both its import (56\%) and export (61\%) activity was with the United States. This represents almost fourfold greater bilateral dependence on the part of Canada. In some sectors, the United States holds a dominant or near monopoly/monopsony position in Canadian trade. Examples of the former are Canadian import market shares of over $70 \%$ in Agriculture, 
Mining, Paper, Rubber, NonFerrous Metals, Wood and Metal Products, NonElectrical Machinery, and Transport Equipment. The United States also buys more than three-quarters of Canadian exports of Petroleum, Beverages, Apparel, Iron and Steel, Electrical Machinery, and Other Manufactures.

Nearly three-quarters of all Canadian Manufactured goods are directed to the U.S. market, indicating quite limited scope for bilateral trade diversion as a result of the NAFTA. Indeed, Mexico may have more potential as a diversionary source of Canadian imports and destination for exports. As of 1988, Mexico only met $1 \%$ of Canada's import needs and bought a negligible amount of the latter's exports. These levels are well below its potential, as indicated by the observed Mexican shares in U.S. trade.

The Mexican economy is summarized in Table 3, and these numbers clearly delineate structural differences vis-à-vis its northern trading partners. As one might expect, Mexico is two to three times more Primary-intensive than the more industrialized countries. Its Manufacturing concentration is more comparable, largely because of a relatively smaller service economy. Demand is also oriented much more toward subsistence and Manufacturing necessities (e.g., Food Processing) and less to Services.

Trade shares are also consistent with intuition about Mexico's comparative advantages, with almost half (44\%) of exports from Primary sectors and $87 \%$ of imports in Manufacturing. One striking difference is the ratio of labor to capital value added, which in some sectors is an order of magnitude less than in the more affluent countries. Mexico is generally more trade dependent than the United States but less so than Canada, with $12 \%$ exports in gross output and $24 \%$ imports in total demand. The sectoral patterns of this dependence vary considerably from the other two countries, with much greater Primary export dependence and more variation in Manufacturing import dependence.

Mexico exhibits about the same average level of U.S. trade dependence as Canada, but its composition is quite different. The United States has an even more dominant position in selected Mexican sectors, with a share of more than $80 \%$ in six Mexican import markets and ten Mexican cxport markets. Overall, $81 \%$ of Mexican Manufacturing exports went to the United States in 1988. Again, this implies that trade diversion between members of the NAFTA is more likely than with respect to countries outside the region.

The structural data reviewed in this section provide considerable detail on the three domestic economies and their trade linkages, and the detailed portrait is generally consistent with intuition about them. We see the United States at the center of a regional economy, the largest and most self-sufficient member. Its northern neighbor shares many of its attributes as a relatively affluent and industrialized country, but Canada cxhibits considcrably morc bilateral trade dependence and less diversity in domestic structure and trade. Mexico is unique in having a large subsistence sector, low value added shares for labor across the economy, even higher trade dependence, and less trade diversity.

All these structural features will have important implications for adjustment patterns which would ensue from trade liberalization. Even this detailed information cannot be considered in isolation, however, since market conduct in each country and sector will also have a decisive influence on the adjustment process. It is on this point where the specification in the CGE model may be most fruitfully examined, particularly in light of the U.S. market share dominance in many Canadian and Mexican sectors. 


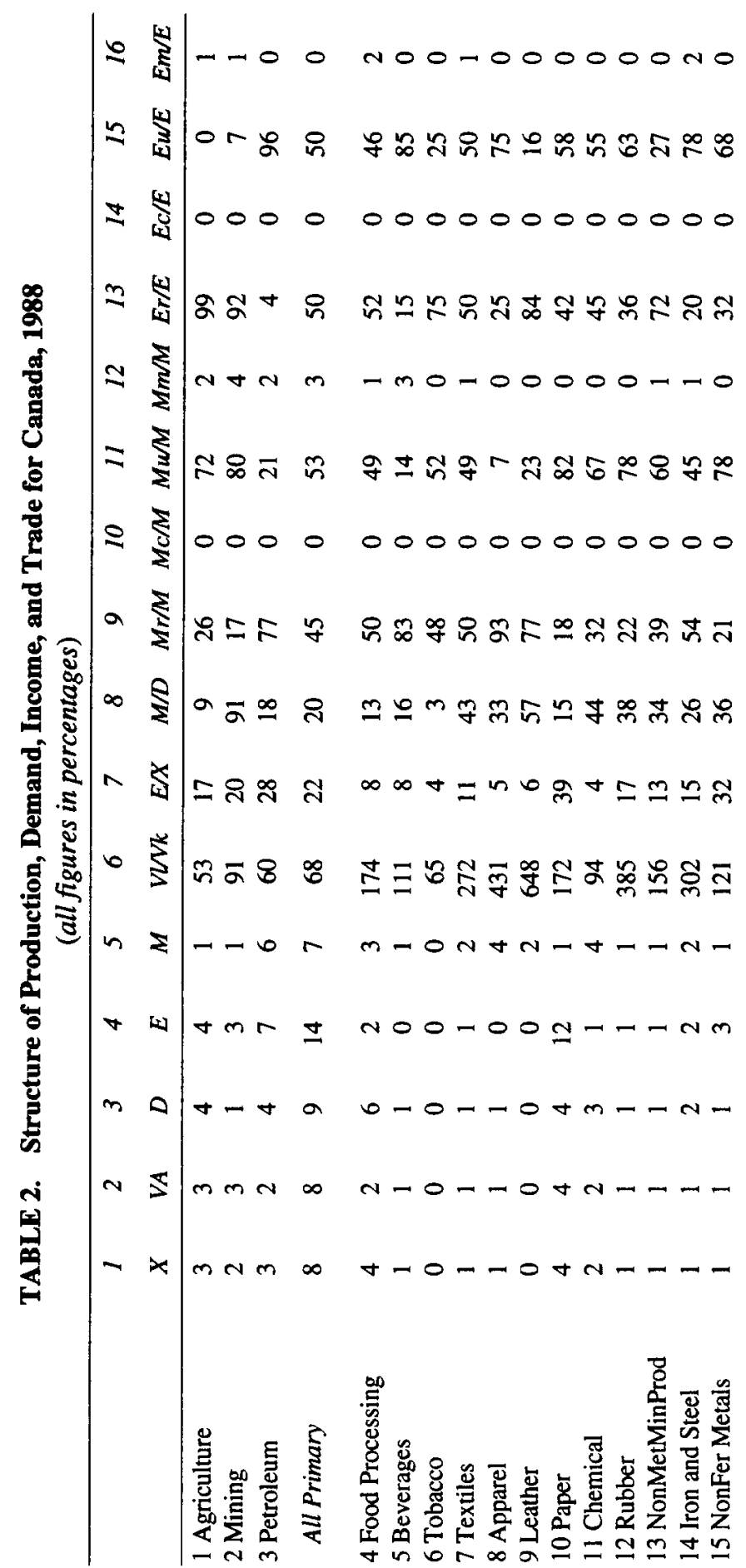




\begin{tabular}{|c|c|c|c|c|}
\hline $0-000$ & 0 & 000000 & 0 & 0 \\
\hline F & \pm & 000000 & 0 & $\overline{0}$ \\
\hline 00000 & 0 & 000000 & 0 & 0 \\
\hline ๓กีล์ & 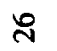 & $\circ 88888$ & 8 & m \\
\hline nNT- & - & 000000 & 0 & - \\
\hline $\bar{N}: \nabla-m$ & $\infty$ & 000000 & 0 & 冓 \\
\hline 00000 & 0 & 000000 & 0 & 0 \\
\hline నొ 办 ల్ల & $\vec{m}$ & ○ 8888 & 8 & 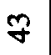 \\
\hline$\ddot{n}$ 음 & 吊 & O $\forall \sigma o$ & $=$ & $\approx$ \\
\hline 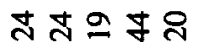 & $\approx$ & $0 \nabla \forall \varrho-N$ & $m$ & 2 \\
\hline œ 쥼윰 & $\vec{n}$ & 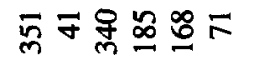 & 㝏 & 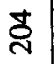 \\
\hline$m \sim \infty 06$ & 莴 & OON & gे & 8 \\
\hline$\infty 0+\bar{m} r$ & $\approx$ & $0-m 0-m$ & $\underline{m}$ & 8 \\
\hline$n n+n N$ & กี & $\infty-n \in n g$ & gి & 8 \\
\hline$m-N m-$ & $\vec{N}$ & $a+\infty \infty$ 으유 & $\infty$ & 8 \\
\hline $\tan \sigma$ & $\stackrel{\infty}{\infty}$ & $a n=-\infty=$ & 芩 & 8 \\
\hline 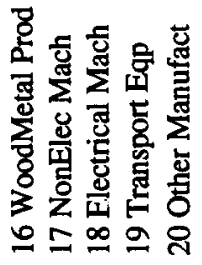 & 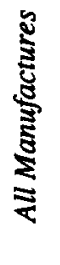 & 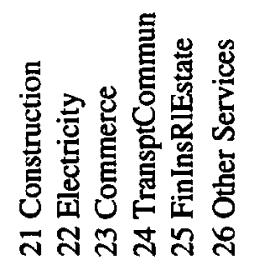 & 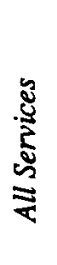 & 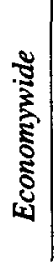 \\
\hline
\end{tabular}




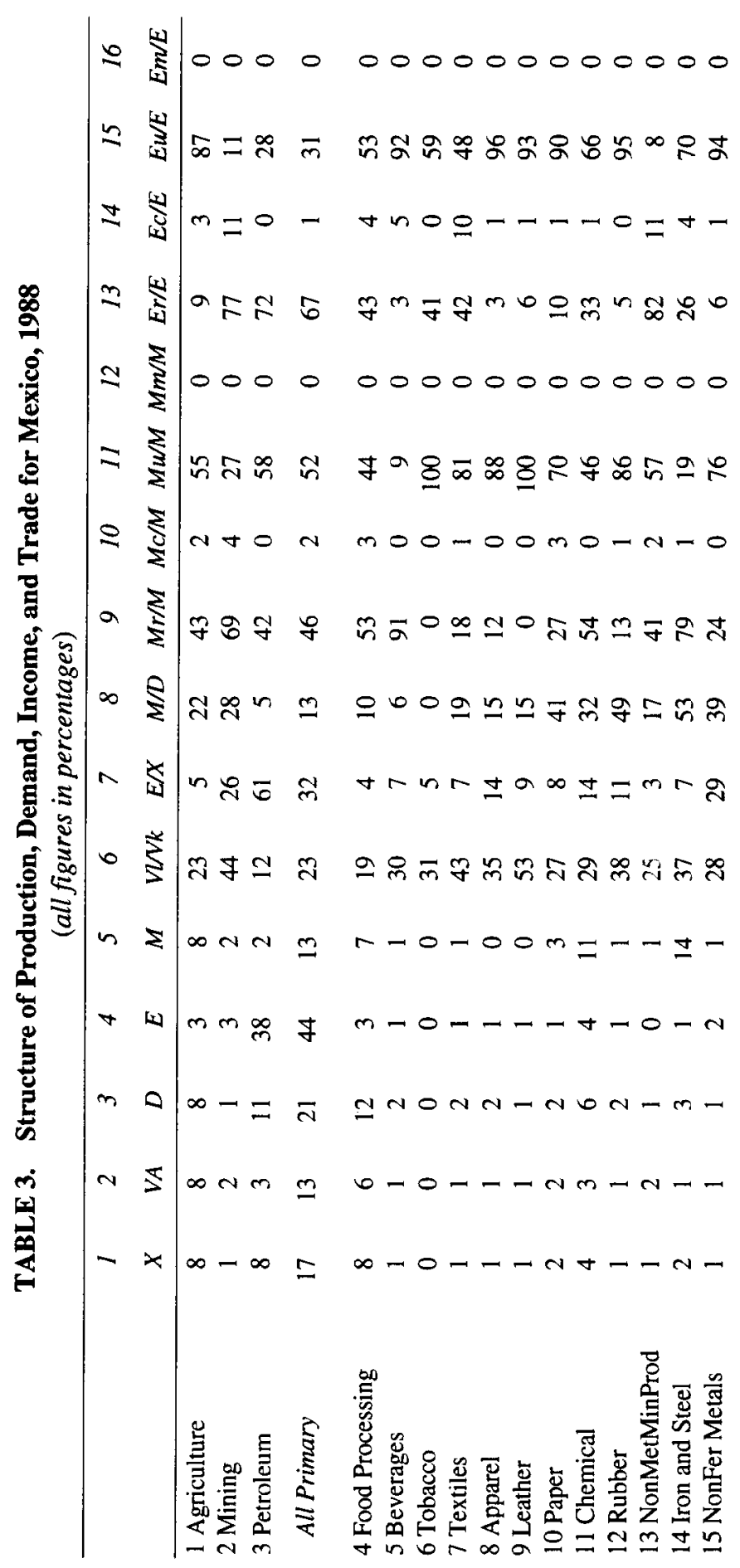




$$
\begin{aligned}
& 00000000000000
\end{aligned}
$$

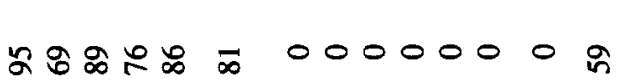

$$
\begin{aligned}
& n 4 m+m \rightarrow 0000000 \mathrm{~m} \\
& \text { masi }=n 0000000 \mathrm{~m} \\
& 00000000000000
\end{aligned}
$$

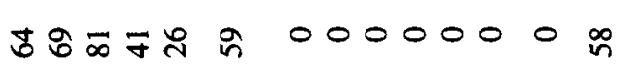

$$
\begin{aligned}
& \text { omono- } 0000000 \text { h }
\end{aligned}
$$

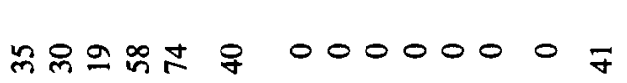

$$
\begin{aligned}
& \text { मnं } \\
& \text { 음ํำ }
\end{aligned}
$$

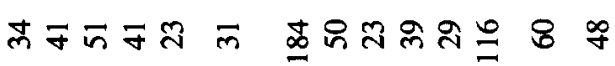

$$
\begin{aligned}
& n=\infty \pi n \text { n } 00000008 \\
& \text { mmg Nm in } 00000008 \\
& \operatorname{tron} n \infty \sin \pi \\
& --4-m+4 n \infty \infty \frac{48}{4} \\
& m m+n-80-n n n 0 \% 8
\end{aligned}
$$

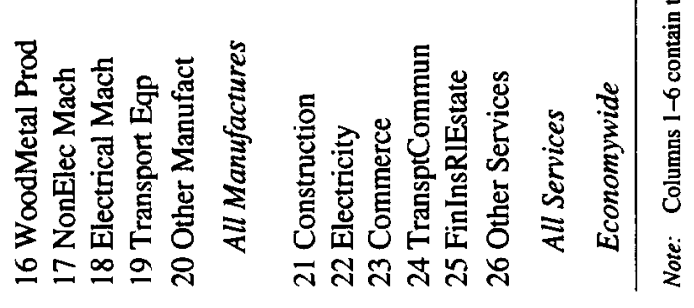




\section{AN OVERVIEW OF NORTH AMERICAN PROTECTION PATTERNS}

Domcstic policics which distort the pattern of international trade fall into three broad categories: import control measures, export controls or subsidies, and domestic policies such as producer subsidies which distort industry costs and sectoral resource allocation. We focus on the role of the first category of trade distortion. Import restraints themselves take a wide variety of forms, including tariffs and surcharges, quantitative restrictions, and supervisory mechanisms such as registration and inspection requirements. In terms of CGE modeling, the most tractable type of import restraint to specify and simulate is an ad valorem tariff. As the discussion of the model in the next section explains, however, allowance has also been made for the principal type of nontariff barriers (NTBs), quantity restrictions (quotas or VERs) which induce an ad valorem premium distortion on domestic prices. These two categories of protection represent the majority of import coverage by distortionary trade control measures. This section presents the data and methods used to calibrate the CGE model for the most significant import distortions affecting North American trade.

Four primary data sources were consulted to obtain the protection estimates used in this study. The first is the 1988 three-country SAM discussed above. The SAM includes estimates of sectoral tariff and other duty collections for each country, bilaterally for North American partners and with respect to the rest of the world. These collections were used to impute ad valorem equivalent tariff rates (as opposed to statutory rates) which measure the rates of actual distortion against the world prices of imports. These estimates are presented in percentage terms in Table 4. As the trade-weighted averages indicate, North American nominal protection is relatively low by world standards, although some sectoral flows are highly distorted.

Despite the low tariff protection which is apparent from the SAM, other evidence suggests that NTBs are pervasive enough to exert a significant effect on trade prices in the region, particularly in some sectors. As a second source of information for the model, we consulted the public and private published sources on estimates of ad valorem equivalents for NTBs in the United States, Canada, and Mexico. The results of this survey are summarized in Table 5. ${ }^{6}$ Actual estimates of ad valorem equivalents for specific sectors are rather scarce, but a number of authors have attempted to impute and use these values in preference to the assumption of no NTB price distortions across the board.

The third source of data is by far the most detailed, consisting of three-digit SITC tabulations of bilateral import NTBs for the United States, Canada, and Mexico and the same three countries plus a ROW aggregate as exporters. The data were obtained by extraction from the combined UNCTAD-GATT database of four-digit trade control measures in Geneva (see, e.g., UNCTAD 1987). This information is too detailed for inclusion in the paper but it is summarized for ten aggregate NTB categories in Tables 6,7 , and $8 .^{7}$ The data were also aggregated from three-digit SITC to the 26 sectors of the CGE model. These estimates revealed that North American trade is subject to extensive nontariff barriers.

Implementation of the CGE model with tariff data or ad valorem equivalent estimates is a routine matter. While the NTB data in Tables 6-8 give very detailed information on the composition of NTB protection, however, they do not precisely measure induced price disadvantages against covered imports. The translation of such NTB coverage measures into 
TABLE 4. Nominal Import Collection Rates, 1988

\begin{tabular}{|c|c|c|c|c|c|c|c|c|c|}
\hline & \multicolumn{3}{|c|}{ United States } & \multicolumn{3}{|c|}{ Canada } & \multicolumn{3}{|c|}{ Mexico } \\
\hline & ROW & Canada & Mexico & ROW & USA & Mexico & ROW & USA & Canada \\
\hline 1 Agriculture & 1 & 2 & 6 & 1 & 1 & 2 & 0 & 1 & 0 \\
\hline 2 Mining & 0 & 0 & 1 & 0 & 0 & $\mathbf{0}$ & 0 & 2 & 0 \\
\hline 3 Petroleum & 1 & 0 & 0 & 0 & 1 & 0 & 1 & 4 & 0 \\
\hline All Primary & 1 & 1 & 2 & 0 & 0 & 0 & 0 & 1 & 0 \\
\hline 4 Food Processing & 4 & 2 & 6 & 4 & 4 & 5 & 1 & 3 & 2 \\
\hline 5 Beverages & 3 & 3 & 2 & 35 & 35 & 35 & 0 & 0 & 0 \\
\hline 6 Tobacco & 10 & 17 & 8 & 8 & 8 & $\mathbf{0}$ & 0 & $\mathbf{0}$ & 0 \\
\hline 7 Textiles & 10 & 6 & 7 & 12 & 12 & 12 & 3 & 2 & 0 \\
\hline 8 Apparel & 19 & 9 & 16 & 18 & 18 & 18 & 5 & 2 & 0 \\
\hline 9 Leather & 9 & 22 & 5 & 13 & 14 & 0 & 0 & 1 & 0 \\
\hline 10 Paper & 1 & 0 & 2 & 4 & 4 & 0 & 2 & 2 & 3 \\
\hline 11 Chemical & 5 & 17 & 2 & 5 & 5 & 8 & 2 & 3 & 0 \\
\hline 12 Rubber & 6 & 10 & 4 & 7 & 7 & 0 & 4 & 1 & 0 \\
\hline 13 NonMetMinProd & 6 & 1 & 0 & 5 & 5 & 8 & 4 & 8 & 0 \\
\hline 14 Iron and Steel & 4 & 3 & 3 & 4 & 4 & 5 & 1 & 4 & 0 \\
\hline 15 NonFer Metals & 1 & 1 & 0 & 2 & 2 & 0 & 2 & 4 & 0 \\
\hline 16 WoodMetal Prod & 4 & 1 & 2 & 6 & 6 & 6 & 4 & 3 & 0 \\
\hline 17 NonElec Mach & 3 & 1 & 1 & 2 & 2 & 2 & 5 & 3 & 5 \\
\hline 18 Electrical Mach & 3 & 2 & 3 & 4 & 4 & 4 & 7 & 1 & 5 \\
\hline 19 Transport Eqp & 3 & 0 & 2 & 7 & 0 & 7 & 1 & 2 & 1 \\
\hline 20 Other Manufact & 4 & 1 & 3 & 4 & 4 & 5 & 2 & 10 & 0 \\
\hline All Manufactures & 5 & 1 & 3 & 7 & 3 & 5 & 3 & 2 & 2 \\
\hline 21 Construction & 0 & 0 & 0 & 0 & 0 & 0 & 0 & 0 & 0 \\
\hline 22 Electricity & 0 & 0 & 0 & 0 & 0 & 0 & 0 & 0 & 0 \\
\hline 23 Commerce & 0 & 0 & 0 & 0 & $\mathbf{0}$ & 0 & 0 & 0 & 0 \\
\hline 24 TransptCommun & 0 & 0 & 0 & 0 & 0 & 0 & 0 & 0 & 0 \\
\hline 25 FinInsRlEstate & 0 & 0 & 0 & 0 & 0 & 0 & 0 & 0 & 0 \\
\hline 26 Other Services & 0 & 0 & 0 & 0 & 0 & 0 & 0 & 0 & 0 \\
\hline All Services & 0 & 0 & 0 & 0 & 0 & 0 & 0 & 0 & 0 \\
\hline Economywide & 3 & 1 & 3 & 4 & 2 & 4 & 2 & 2 & 2 \\
\hline
\end{tabular}

Source: Roland-Holst, Reinert, and Shiells (1993).

Note: Averages weighted by bilateral trade.

ad valorem equivalents is a difficult and uncertain exercise which we have not attempted at this stage. ${ }^{8}$

A fourth and final source of information on North American trade distortions comes from intercountry price comparison data. Relatively good information on comparable commodity groups is now available from the International Comparison Project (ICP) sponsored by the United Nations, World Bank, and University of Pennsylvania (discussed in Kravis, Heston, and Summers 1982). The researchers who assembled this database have gone to great lengths to achieve comparability of commodity groups, and we feel North American comparisons 
TABLE 5. Ad Valorem NTB Equivalents

\begin{tabular}{|c|c|c|c|c|c|c|c|c|c|}
\hline & \multicolumn{3}{|c|}{ United States } & \multicolumn{3}{|c|}{ Canada } & \multicolumn{3}{|c|}{ Mexico } \\
\hline & ROW & Canada & Mexico & ROW & $\begin{array}{l}\text { United } \\
\text { States }\end{array}$ & Mexico & ROW & $\begin{array}{l}\text { United } \\
\text { States }\end{array}$ & Canada \\
\hline 1 Agriculture & 50 & 7 & 50 & 12 & 12 & 12 & 6 & 6 & 6 \\
\hline 2 Mining & 0 & 0 & $\mathbf{0}$ & 0 & 0 & 0 & 10 & 10 & 10 \\
\hline 3 Petroleum & 0 & 0 & $\mathbf{0}$ & 0 & $\mathbf{0}$ & $\mathbf{0}$ & 0 & 0 & 0 \\
\hline All Primary & 8 & 1 & 10 & 1 & 3 & 2 & 6 & 5 & 7 \\
\hline 4 Food Processing & 0 & 9 & 0 & 0 & 0 & 0 & 15 & 15 & 15 \\
\hline 5 Beverages & 0 & 9 & 0 & 0 & 0 & 0 & 19 & 19 & 19 \\
\hline 6 Tobacco & 0 & 1 & $\mathbf{0}$ & 0 & 0 & 0 & 20 & 20 & 20 \\
\hline 7 Textiles & 5 & 5 & 5 & 0 & 0 & 0 & 15 & 15 & 15 \\
\hline 8 Apparel & 47 & 1 & 47 & 0 & 0 & 0 & 20 & 20 & 20 \\
\hline 9 Leather & 0 & 0 & 5 & 4 & 4 & 4 & 17 & 17 & 17 \\
\hline 10 Paper & 0 & 0 & 5 & 1 & 1 & 1 & 5 & 5 & 5 \\
\hline 11 Chemical & 1 & 1 & 1 & 0 & 0 & 0 & 9 & 9 & 9 \\
\hline 12 Rubber & 0 & 0 & 5 & 0 & 0 & 0 & 18 & 18 & 18 \\
\hline 13 NonMetMinProd & 0 & 0 & 5 & 0 & 0 & 0 & 15 & 15 & 15 \\
\hline 14 Iron and Steel & 4 & 4 & 4 & 1 & 1 & 1 & 7 & 7 & 7 \\
\hline 15 NonFer Metals & 4 & 4 & 4 & 1 & 1 & 1 & 11 & 11 & 11 \\
\hline 16 WoodMetal Prod & 13 & 1 & 13 & 1 & 1 & 1 & 16 & 16 & 16 \\
\hline 17 NonElec Mach & 0 & 3 & 0 & 0 & 0 & 0 & 17 & 17 & 17 \\
\hline 18 Electrical Mach & 0 & 0 & 0 & 1 & 1 & 1 & 12 & 12 & 12 \\
\hline 19 Transport Eqp & 32 & 0 & 0 & 0 & 0 & 0 & 18 & 18 & 18 \\
\hline 20 Other Manufact & 0 & 0 & 0 & 1 & 1 & 1 & 0 & 0 & 0 \\
\hline All Manufactures & 10 & 1 & 3 & 0 & 0 & 0 & 13 & 14 & 14 \\
\hline 21 Construction & 0 & 0 & 0 & $\mathbf{0}$ & 0 & 0 & 0 & 0 & 0 \\
\hline 22 Electricity & 0 & 0 & 0 & $\mathbf{0}$ & $\mathbf{0}$ & 0 & 0 & 0 & 0 \\
\hline 23 Commerce & $\mathbf{0}$ & 0 & 0 & $\mathbf{0}$ & $\mathbf{0}$ & 0 & 0 & 0 & 0 \\
\hline 24 TransptCommun & 0 & 0 & 0 & 0 & $\mathbf{0}$ & $\mathbf{0}$ & 0 & 0 & 0 \\
\hline 25 FinInsRIEstate & $\mathbf{0}$ & 0 & 0 & 0 & 0 & 0 & 0 & 0 & 0 \\
\hline 26 Other Services & 0 & 0 & 0 & 0 & 0 & 0 & 0 & 0 & 0 \\
\hline All Services & 0 & $\mathbf{0}$ & 0 & 0 & 0 & $\mathbf{0}$ & 0 & 0 & 0 \\
\hline Economywide & 3 & 1 & 3 & 4 & 2 & 4 & 2 & 2 & 2 \\
\hline
\end{tabular}

Note: Columns $1-6$ contain totals; $7-17$ contain denominator-weighted averages.

with these data should be valid across the relatively aggregated sectors of the present model. Price relatives for the three countries are given in Table 9.

The columns of the table list ratios of sectoral prices to domestic average prices, all of which were obtained from purchasing power parity (PPP) price indices in the ICP database. Price relatives can differ between countries for a variety of reations, including product and taste differences, regulation, and domestic and border market distortions. It is apparent that 


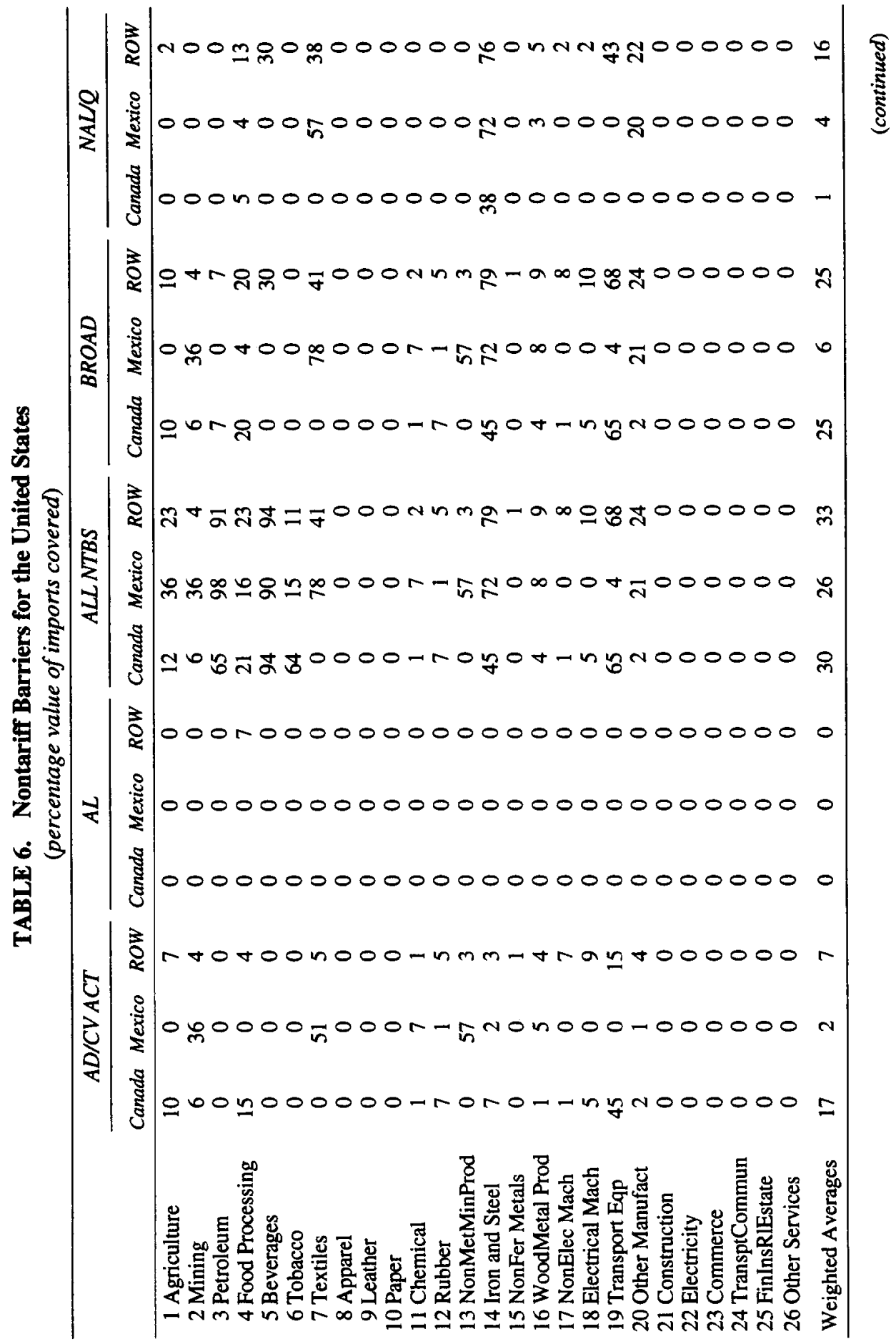




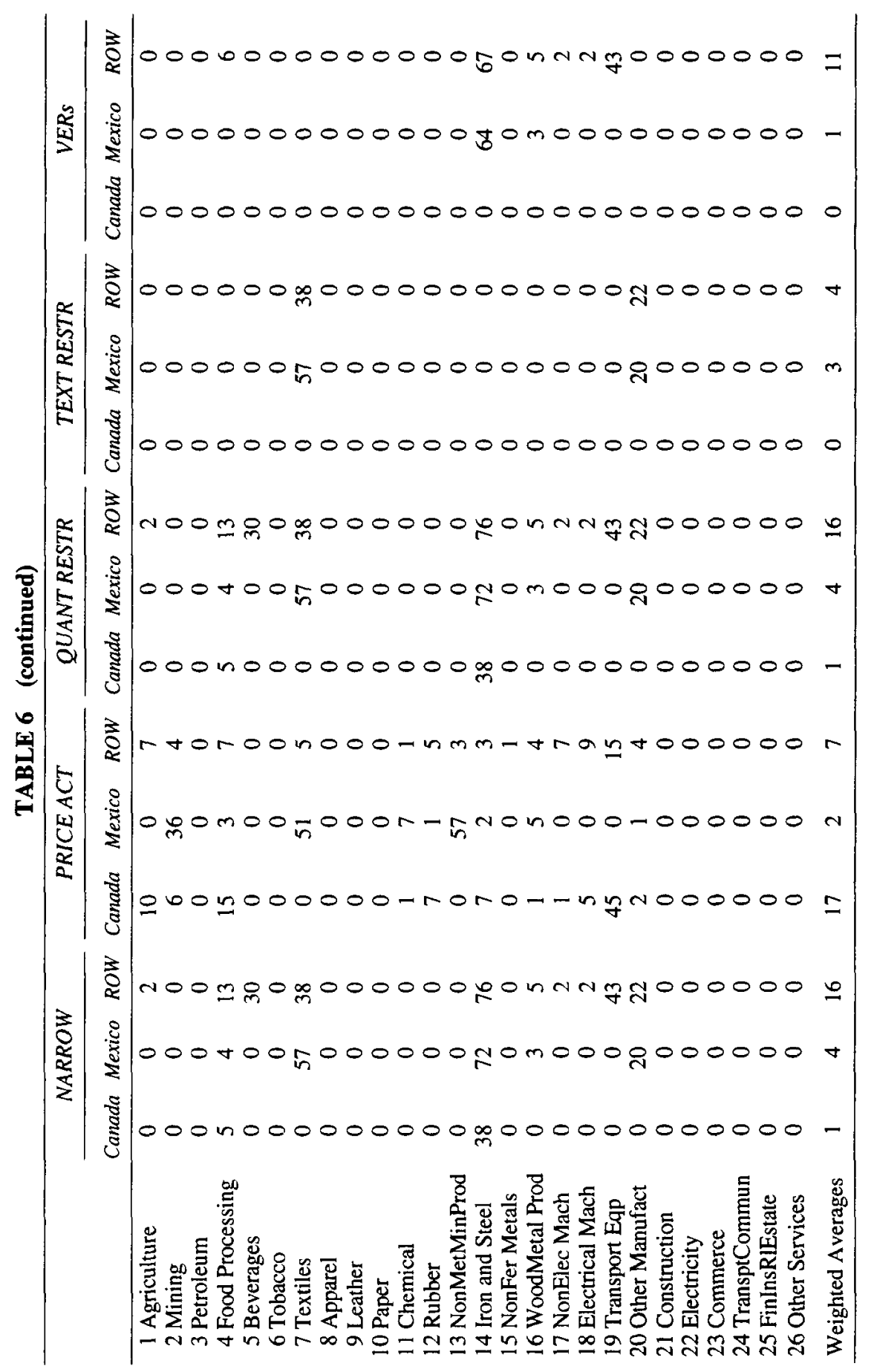




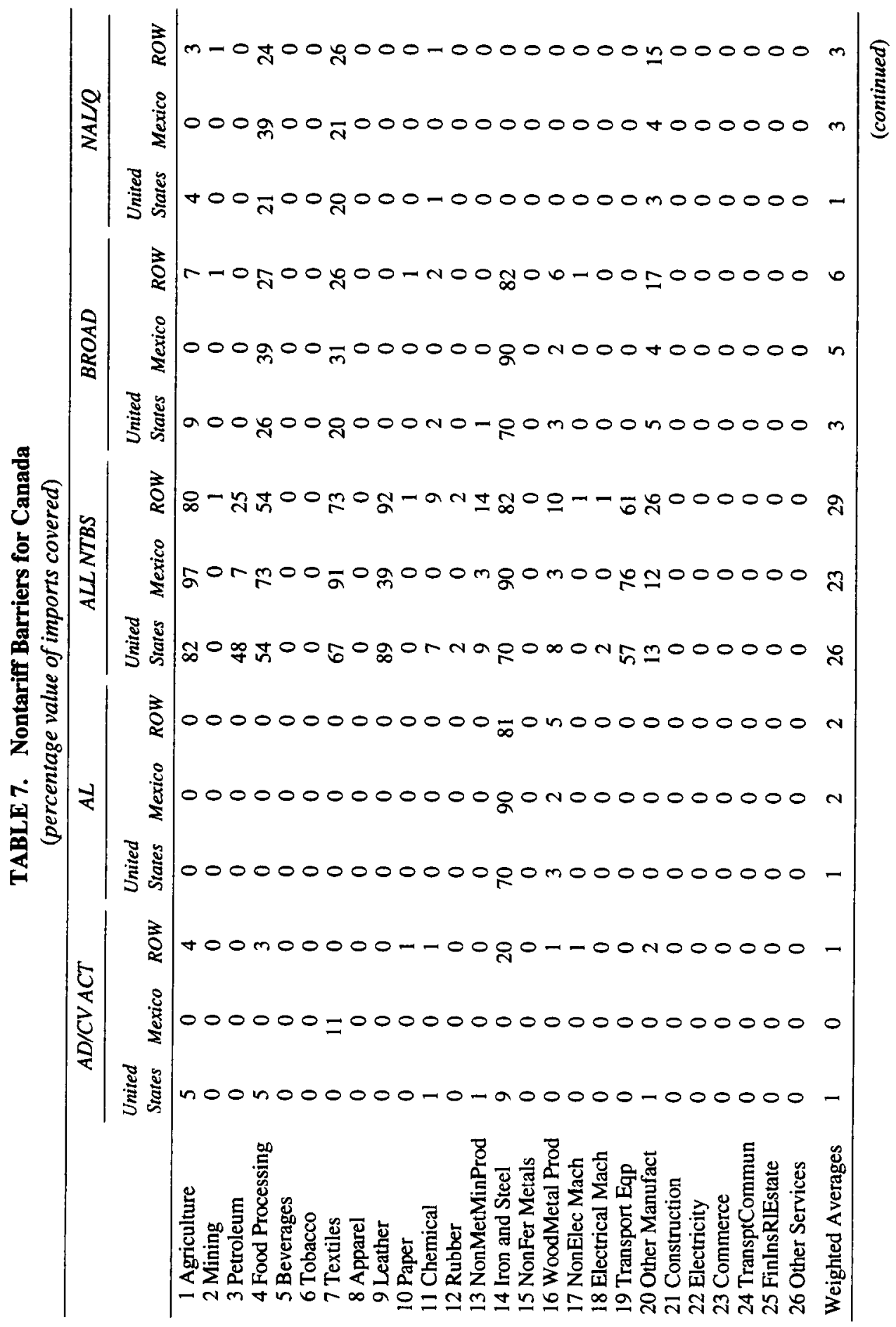




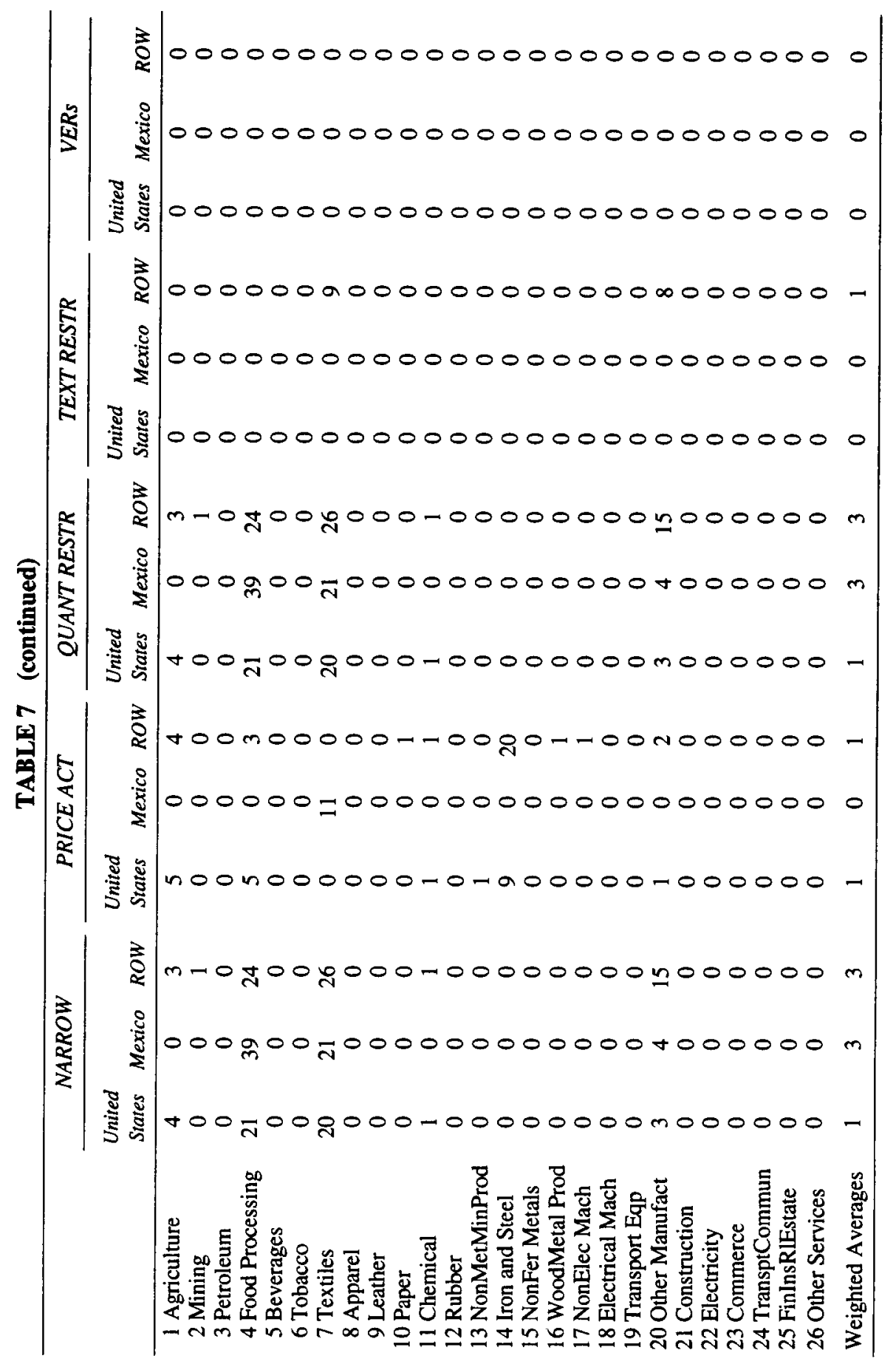




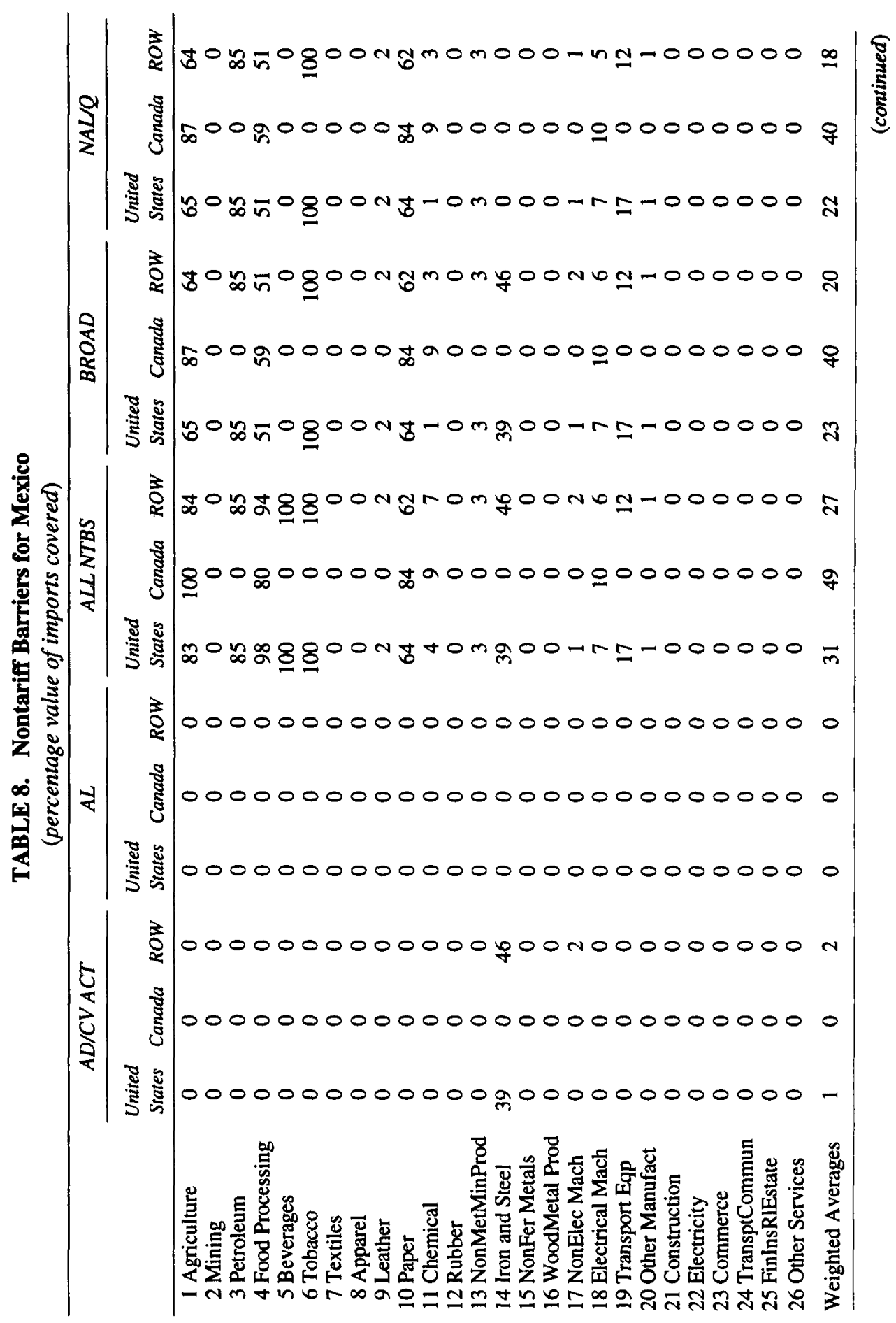




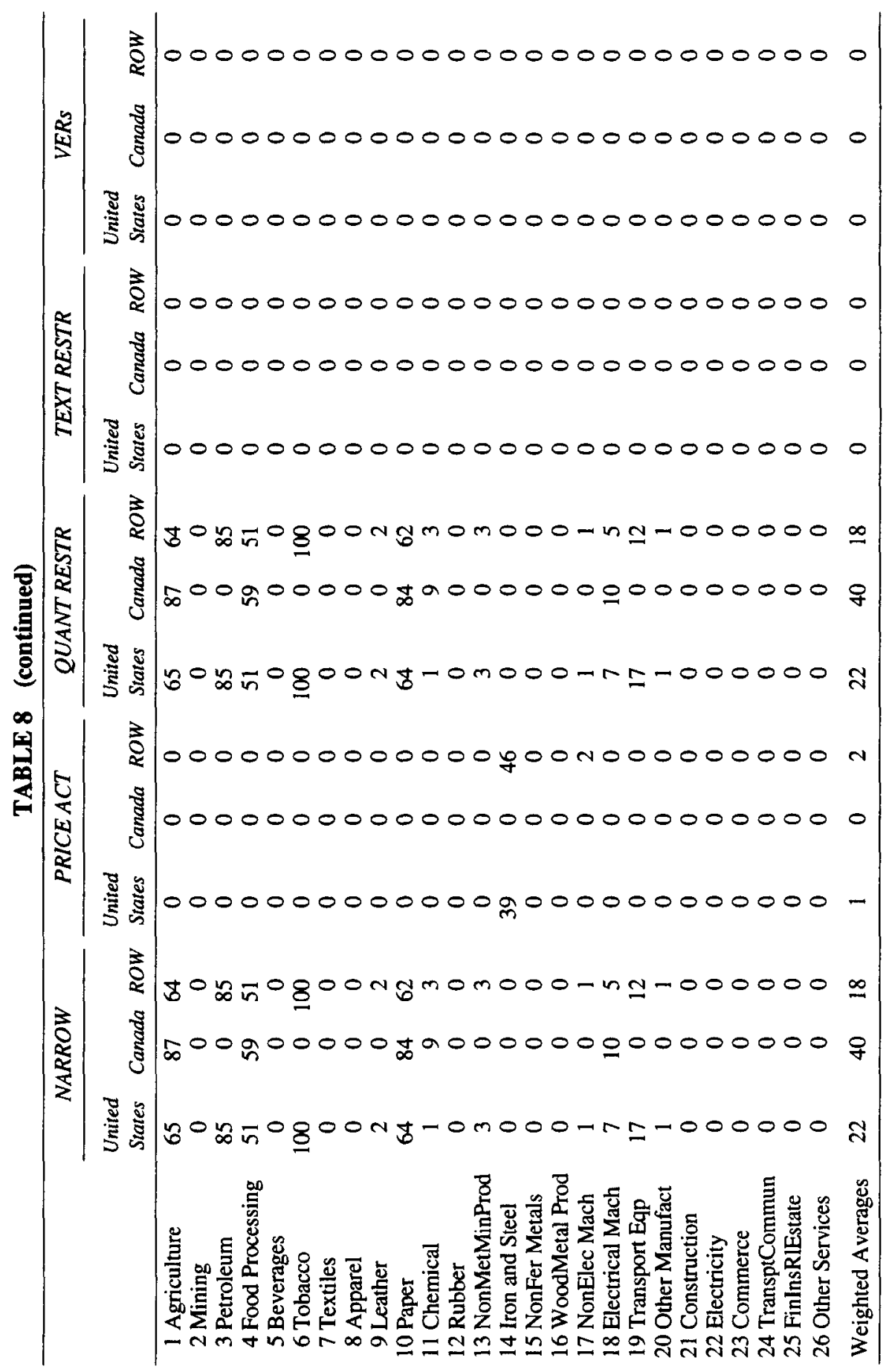


TABLE 9. Domestic Price Relatives Based on Purchasing Power Comparisons (averages are weighted by domestic sectoral output)

\begin{tabular}{|c|c|c|c|}
\hline & United States & Canada & Mexico \\
\hline 1 Agriculture & 1.30 & 1.28 & .87 \\
\hline 2 Mining & .83 & .81 & .86 \\
\hline 3 Petroleum & 1.45 & 1.25 & 1.79 \\
\hline All Primary & 1.35 & 1.17 & 1.29 \\
\hline 4 Food Processing & 1.22 & 1.24 & .92 \\
\hline 5 Beverages & 1.23 & 1.08 & 1.12 \\
\hline 6 Tobacco & 1.49 & 1.60 & .87 \\
\hline 7 Textiles & 1.14 & .90 & .75 \\
\hline 8 Apparel & 1.02 & 1.08 & .66 \\
\hline 9 Leather & .91 & 1.18 & .61 \\
\hline 10 Paper & .98 & 1.25 & .76 \\
\hline 11 Chemical & .89 & 1.03 & .81 \\
\hline 12 Rubber & 1.48 & 2.66 & .99 \\
\hline 13 NonMetMinProd & 1.00 & 1.00 & 1.00 \\
\hline 14 Iron and Steel & 1.00 & 1.00 & 1.00 \\
\hline 15 NonFer Metals & 1.00 & 1.00 & 1.00 \\
\hline 16 WoodMetal Prod & 1.28 & .77 & .45 \\
\hline 17 NonElec Mach & 1.18 & 1.10 & 1.40 \\
\hline 18 Electrical Mach & 1.22 & 1.12 & 1.56 \\
\hline 19 Transport Eqp & 1.26 & 1.17 & 1.66 \\
\hline 20 Other Manufactures & 1.08 & 1.22 & .94 \\
\hline All Manufactures & 1.16 & 1.14 & 1.04 \\
\hline 21 Construction & 1.15 & 1.21 & .72 \\
\hline 22 Electricity & 1.02 & .40 & .94 \\
\hline 23 Commerce & .82 & 1.11 & .41 \\
\hline 24 TransptCommun & .79 & 1.20 & .28 \\
\hline 25 FinInsRlEstate & 1.10 & 1.55 & .48 \\
\hline 26 Other Services & .79 & 1.38 & .54 \\
\hline All Senvices & .91 & 1.14 & .56 \\
\hline Economywide & 1.01 & 1.21 & .84 \\
\hline
\end{tabular}

Source: Kravis, Heston, and Summers (1982).

significant price disparities do exist between the countries of the North American group, and casual inspection reveals that most of the factors just mentioned are probably at work. As the three economies become integrated into a single market, however, it is reasonable to expect greater price harmonization. More specifically, there appears to be a substantial degree of conformality between NTB coverage (Tables 6-8) and these price disparities, particularly in sectors with high import shares and the observed price disparities far exceed nominal protection levels in force at the time (Table 4). Thus nontariff protection appears to impose significant price disadvantages on regional imports. 


\section{A CALIBRATED GENERAL EQUILIBRIUM MODEL FOR TRADE POLICY ANALYSIS}

The three-country calibrated general equilibrium (CGE) model described here is in most respects typical of comparative static, multisectoral, economy wide models in use today. ${ }^{9}$ Generally speaking, all these models simulate price-directed resource allocation in commodity and factor markets. They maintain detailed information on sectoral prices, output, trade, consumption, and factor use in a consistent framework which also accounts for aggregates such as income, employment, revenue, and so forth. The present model differs from conventional CGE specifications in three important ways. ${ }^{10} \mathrm{First}$, it is a three-country model, so domestic supply, demand, and bilateral trade for the United States, Canada, and Mexico countries are fully endogenous at a 26-sector level of aggregation. The three countries maintain six pairs of 26-sector trade flows between them, governed by six endogenous price systems (U.S.-Canada, U.S.-Mexico, and Canada-Mexico imports and exports). With respect to the Rest of the World (ROW), each country faces import supply and cxport demand schedules, totaling six more price systems (U.S.-ROW, Canada-ROW, and Mexico-ROW imports and exports). ${ }^{11}$

The extent of price adjustments, as well as the volume and pattern of trade creation and trade diversion, are each important factors in determining the ultimate welfare effects of bilateral trade policy. A second important feature of the model is its differentiated product specification for the demand and supply in tradeable commodities. Domestic demand is constituted of goods which are differentiated hy origin (domestic goods, imports from North American trading partners, and imports from ROW) and domestic production is supplied to differentiated destinations (domestic market, exports to the trading partner, and exports to ROW). Similar devices appear elsewhere in the CGE literature; the present model uses a CES specification for demand and CET for supply. ${ }^{12}$

Third, the CGE model permits an appraisal of the role of increasing returns to scale in determining the ultimate effects of trade policy. A number of authors have demonstrated that the presence of scale economies can significantly influence the gains from trade liberalization (examples include Harris 1984 and de Melo and Tarr 1992). The direction and magnitude of this influence generally depend upon the direction and magnitude of the induced scale adjustments, with aggregate efficiency and welfare moving in the opposite direction from average costs. The direction of average cost adjustment depends on the specification of industry conduct, partly a methodological and partly an empirical issue. The magnitude of cost adjustments (shape and scale of average cost curves) is purely an empirical question.

Given the diversity of the domestic markets involved and the absence of a clear methodological consensus on modelling firm behavior, we chose a relatively parsimonious specification of market structure and two alternatives for market conduct under increasing returns to scale. This approach will facilitate interpretation of the present results as general indicators of scale effects. Increasing returns are specified with one parameter, a cost disadvantage ratio (CDR) which measures the share by which average total cost exceeds marginal cost, $(A T C-M C) / A T C$ for the aggregate or representative firm in each sector. This in turn, is calibrated to an equivalent fixed cost for the observed output and factor use in each sector (for details, see de Melo and Tarr 1992). Estimates of the magnitude of unrealized scale economies in the base case are obtained from a variety of sources and reproduced in the Appendix. 
For firm conduct, the first case assumes a kind of contestability, with no firm entry, where a representative firm prices at average cost. Since the number of firms (or cost curves) in the industry is constant, this implies that efficiency varies directly with industry output. If trade policy induces an expansion of industry output, the incumbent competitive firms in this scenario move down their average cost curves, pricc accordingly, and confer the newly realized scale economies upon domestic consumers. Sectoral output contraction leads to the opposite effects.

The second specification of firm behavior uses the so-called conjectural variations method to evaluate Cournot behavior in each sector. Market entry and exit are assumed to be costless, and firms implement a markup pricing rulc of the form $(P-M C) / P=1 / n \varepsilon$, where $E$ is the domestic price elasticity of demand and $n$ denotes the number of firms in the industry. It is further assumed that firms maintain base profit rates (normalized to zero in this model). Thus, prices and the (now endogenous) number of firms are jointly determined by the elasticity of demand and average costs. In this case, ultimate realization of scale economies depends on per firm average costs, and market entry or exit can alter the effects of aggregate sectoral expansion or contraction. For example, sectoral output expansion, which would have yielded efficiency gains for the fixed population of incumbent firms, may in fact induce inefficient firm entry where new firms "crowd in" on incumbents in their respective sectors, driving them up their average cost curves. On the other hand, industry contraction need not contribute to higher average costs if firm rationalization countcracts this, allowing survivors to move down their cost curves.

The North American CGE model was calibrated to the 1985 SAM discussed in the second section. Structural parameters of the model were obtained by calibration, direct estimation, or imputation from other sources. Calibrated values were obtainable for most share parameters, input-output coefficients, nominal ad valorem taxes, and tariffs from the SAM itself. Employment and capital stock data were obtained from official publications. The basic data source for behavioral parameters was a weighted aggregation of detailed parameters compiled for the United States by Reinert and Roland-Holst (1991). The U.S. parameters were applied to Canada and Mexico except for those cases where alternatives were available. Elasticitics of substitution between labor and capital for Canada were taken from Delorme and Lester (1990). Upper-tier Armington elasticities for Mexico were taken from Sobarzo (1991). ${ }^{13}$

\section{SIMULATION RESULTS}

This section presents the results of a variety of trade policy simulation experiments with the North American CGE model. The policies considered entail trade liberalization between the three countries, including removal of nominal protection as well as NTB-induced price distortions, but each North American trading partner maintains its existing protection with respect to the rest of the world. ${ }^{14}$ The results indicate that all three countries could realize substantial gains from more liberal trade relations, and that each economy would undergo significant shifts in its trade patterns and in the composition of its domestic production. The latter vary with the degree of prior trade dependence but imply that considerable structural adjustment may be occasioned by a new trade regime. It is also apparent from these simulations that the paltern of adjustment would vary significantly, depending upon whether the liberalization negotiated in the NAFTA were to include nontariff sources of price distortions. 
In the presence of unrealized scale economies of the type described in the previous section, the welfare gains from liberalization can be even greater, but again their scope and composition depend upon whether the liberalization is partial or complete. The specification of market conduct under increasing returns also influences both the gains from liberalization and the pattern of adjustment. The results are presented in three stages, beginning with a description of the experiments, followed by discussion of aggregate results for all experiments, and ending with detailed sectoral discussion of two representative experiments.

\section{Description of the Simulation Experiments}

The aggregate results below were obtained in four simulation experiments. The first of these simulates NAFTA-type nominal tariff removal with constant returns to scale and competitive $(p=M C=A C)$ pricing in all sectors. This experiment provides one reference point in terms of both the policy stimulus and the capacity of the economy to respond efficiently. The second experiment maintains the constant returns, competitive specification under a more extensive liberalization scheme, including nontariff barriers. Using the NTB coverage information in Tables 5-8 above, a liberalization scenario is set forth where North American import prices are calibrated to ad valorem distortions equal to coverage rates plus observed tariffs. For the present analysis, it is assumed that the composition of observed NTB protection reflects the composition of price disadvantages, rather than their precise levels. ${ }^{15}$

The policy specification of the third and fourth experiments corresponds to Experiment 2 , this time taking account of the existence of unrealized domestic scale economies according to the information presented in the Appendix. This technological component increases the scope for efficiency gains to be realized by trade liberalization. In Experiment 3, domestic firms are Cournot competitors with fixed profits and free market entry/exit. In this case, expanding markets will attract new entrants, limiting output expansion and average cost reductions of individual firms (the "crowding in" phenomenon). In Experiment 4, contestable market conduct is assumed to prevail domestically, where incumbent firms price at average cost to forestall new entrants. Here, the number of firms in each sector is essentially fixed, and efficiency varies with total sectoral output.

Before presenting the experimental results, a word about closure of the CGE model. For a simulation model of this type to be fully determined, assumptions must be made about the adjustment process in domestic factor markets, commodity markets, and foreign balances. In the experiments which follow, labor in all three countries is assumed to be mobile between sectors and in excess supply in the aggregate. Thus, the domestic aggregate wage is fixed and aggregate employment varies to meet demand. In each domestic product market, prices are normalized to a fixed numeraire price index weighted by the initial composition of sectoral final demand. On the external accounts, ROW exchange rates are assumed to be flexible while trade balances are fixed. ${ }^{16}$

\section{Aggregate Results}

For each of the four experiments, aggregate results are summarized in Table 10. It is immediately apparent that North American liberalization is beneficial to the regional economies in every case. Equivalent variation welfare effects vary from about $0.1 \%$ of base GDP to over $6 \%$, depending upon the degree of liberalization and the extent to which economies of scale are realized in the adjustment process. In every case, increases in aggregate domestic employment and average rental rates are accompanied by extensive 
sectoral reallocation of labor and capital. Our assumptions of perfectly elastic aggregate labor and inelastic aggregate capital supply are restrictive, and the more likely result would be a combined increase in employment and wages on the one hand, and rentals and foreign capital inflows on the other. ${ }^{17}$ Trade for all three countries increases in each experiment, both within the region and with the rest of the world, with the former significantly outweighing the latter because of strong trade diversion effects.

The results of Experiments 1 and 2 indicate dramatic differences in the implications of tariff-only and more complete liberalization. Aggregate effects generally differ by more than an order of magnitude, and the differences in sectoral adjustments are even more pronounced. Thus, it is doubtful whether the experience of tariff liberalization can give substantive guidance to policymakers contemplating a fuller realization of gains from more liberal North American trade relations.

Experiments 3 and 4 are companions to the second, simulating tariff and NTB liberalization under increasing returns to scale. Judging from these, it is apparent that the aggregate effects of liberalization can differ considerably, depending both upon the extent of unrcalized scale economies and the conduct of domestic firms. If entry and exit are unrestricted and Cournot pricing prevails, the aggregate gains are about the same as would be realized under constant returns and perfect competition. ${ }^{18}$ If firm entry and exit are limited and pricing is contestable, however, then gains from tariff and NTB liberalization could be up to $50 \%$ greater for some countries

Trade diversion and creation play an important role in all the experiments, with NAFTA trade increasing by a larger percent in every case than total trade (rows 6-9). The diversion measures in rows 10 and 11 give a normalized index of the extent to which each country's composition of trade has changed between partners. ${ }^{19}$ The employment adjustment index (row 12) is an analogous measurc of the extent of sectoral labor reallocation.

The dramatic welfare increases under full liberalization (tariffs plus NTBs) represent a standard general equilibrium response. Removal of significant market distortions stimulates efficiency, reducing real costs and prices, stimulating domestic and external demand and employment and ultimately fueling a broadly based expansion of domestic production in all three countries. The aggregate income effects of this are so significant that nearly every sector expands in all three countries, almost uniformly outweighing the benefits of prior protection. Thus, liberalization would appear to be individually rational for most sectors if it can be implemented multilaterally, although this may not have been true of unilateral liberalization. While this appears to support the idea of public intervention to overcome a fallacy of composition in sectoral import protection, however, it should be borne in mind that these results are based on assumptions of factor mobility which do not take account of labor and capital market imperfections or social costs of adjustment. Actual structural adjustments arising from this kind of economic stimulus usually result in dislocations and institutional frictions which also call for mediation by the public sector.

\section{Sectoral Results}

The aggregate results are intuitive and relatively homogeneous, since import distortions lead to expanded trade, intensified comparative advantage, and greater economy-wide and global efficiency. All these contribute to aggregate welfare, but until recent years, they have rarely played a decisive role in the formulation of trade policy. It is individual sectors that seek import protection. For this reason, aggregate income or equivalent variation measures have relatively little to say about the real determinants of trade policy. Beneath the smooth 
TABLE 10. Aggregate Effects of North American Economic Integration (Percentages)

\begin{tabular}{|c|c|c|c|c|c|c|}
\hline & $\begin{array}{l}\text { United } \\
\text { States }\end{array}$ & Canada & Mexico & $\begin{array}{l}\text { United } \\
\text { States }\end{array}$ & Canada & Mexico \\
\hline & \multicolumn{3}{|c|}{ Experiment I } & \multicolumn{3}{|c|}{ Experiment 2} \\
\hline & \multicolumn{3}{|c|}{ CRTS, Tariffs Only } & \multicolumn{3}{|c|}{ CRTS, All Protection } \\
\hline $1 \mathrm{EV}$ Welfare & .07 & .24 & .11 & 1.67 & 4.87 & 2.28 \\
\hline 2 Real GDP & .06 & .38 & .13 & 1.34 & 7.22 & 2.27 \\
\hline 3 Employment & .08 & .61 & .33 & 1.88 & 8.96 & 1.49 \\
\hline 4 Rental Rate & .10 & .94 & .45 & 2.43 & 14.50 & 5.18 \\
\hline 5 Real Exchange Rate & -.09 & .69 & -.21 & -.37 & 4.51 & -3.51 \\
\hline 6 Total Imports & .36 & .64 & 1.15 & 8.95 & 19.54 & 14.74 \\
\hline 7 Total Exports & .27 & 1.20 & 1.12 & 8.05 & 29.43 & 13.06 \\
\hline 8 NAFTA Imports & 1.33 & 1.29 & 1.56 & 36.13 & 28.98 & 21.12 \\
\hline 9 NAFTA Exports & 1.34 & 1.14 & 1.99 & 27.17 & 42.76 & 14.23 \\
\hline 10 Import Diversion & .28 & .72 & .46 & 8.03 & 8.93 & 6.28 \\
\hline 11 Export Diversion & .35 & .07 & 1.03 & 6.07 & 12.39 & 1.13 \\
\hline \multirow{3}{*}{$\begin{array}{l}12 \text { Employment } \\
\text { Adjustment }\end{array}$} & .01 & .18 & .18 & .71 & 4.15 & 4.86 \\
\hline & \multicolumn{3}{|c|}{ Experiment 3} & \multicolumn{3}{|c|}{ Experiment 4} \\
\hline & \multicolumn{3}{|c|}{ IRTS, Cournot } & \multicolumn{3}{|c|}{ IRTS, Contestable } \\
\hline $1 \mathrm{EV}$ Welfare & 1.58 & 4.08 & 2.47 & 2.55 & 6.75 & 3.29 \\
\hline 2 Real GDP & 1.30 & 5.82 & 2.57 & 2.07 & 10.57 & 3.38 \\
\hline 3 Employment & 1.79 & 7.29 & 1.73 & 2.47 & 11.02 & 2.40 \\
\hline 4 Rental Rate & 2.49 & 13.57 & 5.77 & 3.40 & 20.74 & 6.57 \\
\hline 5 Real Exchange Rate & -.25 & 3.11 & -2.71 & -1.04 & 6.89 & -4.30 \\
\hline 6 Total Imports & 8.31 & 18.71 & 15.01 & 12.34 & 24.18 & 17.70 \\
\hline 7 Total Exports & 7.87 & 26.25 & 14.36 & 10.43 & 39.83 & 16.72 \\
\hline 8 NAFTA Imports & 33.71 & 27.87 & 21.25 & 46.44 & 35.07 & 23.82 \\
\hline 9 NAFTA Exports & 26.31 & 39.25 & 15.51 & 32.47 & 55.22 & 17.29 \\
\hline 10 Import Diversion & 7.47 & 8.70 & 6.14 & 9.82 & 9.91 & 5.84 \\
\hline 11 Export Diversion & 5.84 & 12.39 & 1.08 & 6.90 & 13.26 & .58 \\
\hline $\begin{array}{r}12 \text { Employment } \\
\text { Adjustment }\end{array}$ & .45 & 2.28 & 4.69 & .71 & 3.22 & 5.21 \\
\hline
\end{tabular}

veneer of the social welfare function, dramatic sectoral adjustments and tradeoffs generally take place when such policies are implemented. This section discusses these detailed effects for two of the five simulation experiments.

In experiment 3, full North American liberalization with increasing returns to scale and industries in each of the three countries, found them populated by Cournot oligopolists. Such firms price according to a markup rule of the form $(p-M C) / p=1 / n \varepsilon$, where $n$ is the number of firms in the sector and $\varepsilon$ is the own-price elasticity of domestic market demand. The number of firms is endogenous in the Cournot experiment, and it is assumed that market entry and exit are costless. It is also assumed that fixed average sectoral profits are maintained before and after liberalization.

The results of full liberalization for the United States are almost uniformly expansionary, with real output growing several percentage points in most sectors. ${ }^{20}$ The strongest expansion 
is in the transport equipment sector (15.9\%), which had high levels of prior protection but enjoys a sharp increase in domestic and external demand, more than offsetting increased imports. Average costs in this industry drop $2.8 \%$ and this leads to price cutting which makes U.S. products more attractive both at home and abroad. The combined price and income effects of liberalization increase domestic real consumption $18.7 \%$, while exports to the ROW $\left(E_{\mathrm{r}}\right)$, Canada $\left(E_{\mathrm{c}}\right)$, and Mexico $\left(E_{\mathrm{m}}\right)$ increase $19.4 \%, 51.8 \%$, and $24.2 \%$, respectively. Other leading U.S. sectors are Ferrous and Nonferrous metals, Leather, NonElectric Machinery, and Textiles.

The experience of U.S. Transport Machinery is typical of other non-service sectors. While the expansionary effects of full liberalization bid up average factor prices, increasing returns outweigh this in 9 of 19 increasing returns sectors. This allows firms to price more competitively, expanding domestic demand and export opportunities so that output rises in spite of increased import penetration. It is also noteworthy that, despite extensive trade diversion, trade with the Rest of the World increases in most sectors.

Employment increases in every sector of the economy under this fixed wage scenario, although it would be more realistic to expect more sectoral reallocation of workers and some real wage rise. The composition of employment in the U.S. economy does not appear to change significantly, since the large nontradeable sectors expand employment only about half as much as do manufacturers. Capital is fixed in total supply in all experiments and is thus reallocated from sectors which are less compctitive, both those that contract and those whose prices or costs force them into more labor-intensive methods in the face of the capital constraint. In light of the expansionary effects of liberalization, it is reasonable to expect the North American economies to attract more foreign capital in these circumstances and for longer-term effects to be stimulated by increased domestic savings and investment.

Because of its higher degree of regional trade dependency and higher prior protection levels, Canada's adjustment is considerably more dramatic than that of the United States. The same basic processes are driving the adjustment, but this time some sectors expand so dramatically that capital becomes very scarce and over half the expanding sectors are forced to substitute away from it and actually reduce capital use while expanding output. This is, of course, a boon for domestic employment, but it is reasonable to question whether this degree of transformation to more labor-intensive techniques would be feasible. The sectoral output, consumption, and trade results for Canada are similar to the United States in qualitative terms, but this economy expands by over twice as much in terms of percentage real GDP. Such a robust expansion also raises average costs almost across the board, so fewer scale economies can be realized under Cournot bchavior, where new firms are entering growing markets.

Mexico's results are in a sense intermediate between the other two (in percentage terms). Expansion is again broadly based, but more focused on primary and tertiary sectors than is the case for its two industrialized neighbors. Manufacturing capacity does expand in Mexico, especially in Transport Vchicles, but domestic and external demand drive significant relative in Mining, Petroleum, and service infrastructure. Because of its relatively low levels of combined (tariff and NTB) prior protection, Mexico experiences a modest appreciation in its real exchange rate. This is too small to offset the improved pricing of its exports in the liberalization North American region, but it does reduce ROW export demand and thus limits expansion of domestic output.

One arresting result is the $9 \%$ contraction in Mexican agriculture, coinciding with increased import penetration by the United States and Canada and reduced ROW export 
opportunities. The problem is aggravated by constant returns in this sector, which is unable to price competitively in the face of rising factor prices and eventually loses both capital and labor. It is an open question whether different agricultural technologies or land use patterns might be introduced to lower average costs and overcome this difficulty, but this trend has been well established elsewhere.

While the sectoral results for contestable market pricing are broadly comparable to the other increasing returns specification, the gains from full liberalization and sectoral output adjustments are about $50 \%$ higher on average. The contestable model specifies that the number of firms in each sector is fixed, market entry and exit being forestalled by pricing which maintains sectoral profit rates at their base levels. Since the number of firms is fixed, scale economies vary in the same direction as industry output. Because average factor prices inevitably rise in this expansionary scenario, however, the direction of movement in average cost depends upon the ratio of factor price increases to scale adjustments. Individual sectors do expand more in this experiment but, despite this, average costs are lower in most cases under Cournot conduct. It is the moderation of average costs which really impels greater sectoral expansion, via competitive pricing and greater demand expansion.

The U.S. economy again expands in 24 of 26 sectors, with the same leading sectors but higher average growth in all sectors. The same qualitative comparability applies to Canada and Mexico, and both countries also expand more robustly than under Cournot competition. Canada experiences dramatic ROW trade growth because of its nearly $7 \%$ real exchange rate depreciation and very competitive pricing for Transport Vehicles. Given the stronger resource pulls in this country, some sectors have higher average costs under contestable than under Cournot conduct, but overall, the Canadian economy realizes substantial efficiency gains. Mexican agriculture again contracts in the face of regional import penetration and reduced ROW exports, but the remaining sectors of the economy more than compensate for this and additional scale economies realized under contestable pricing raise aggregate welfare half again as much as under Cournot competition.

To summarize the results of the full liberalization experiments, it is apparent that the closer the North American region comes to a unified marketplace, the greater will be its manufacturing prowess and regional self-reliance. All three countries would see substantial expansion of their domestic production, even under the capital constraints imposed in the present model specification. These results also indicate that the potential for trade in this region is far from being fully realized, even when this trade does not crowd out the rest of the world. All three countries exhibit quite substantial trade expansion to nearly all markets, and this new external income fuels broadly based domestic demand expansion and rising average welfare.

\section{CONCLUSIONS AND EXTENSIONS}

This paper represents two objectives of its authors: to assemble an extended dataset on the economic structure and protection patterns for the North American economies, and to implement a general equilibrium simulation model with this information. Although the present work is preliminary, a large body of relevant data has been assembled and used to obtain some estimates of the economic adjustments which would ensue from more liberalized North American trade.

A detailed three-country SAM has been constructed for 1988; it was used here to analyze the composition of production, demand, income, and trade among the United States, Canada, 
and Mexico. Generally speaking, these results bear our conventional wisdom about the three economies. The United States is the largest and most self-sufficient member at the center of the regional economy. Canada is relatively affluent and industrialized, like the United States, but is more dependent on bilateral trade and less diverse in domestic structure and trade. Mexico is distinctive in this group for its large subsistence sector, low value added shares for labor across the country, even higher trade dependency, and less diversity.

The information presented on North American protection patterns indicates that tariff distortions are moderate by world standards. Extensive data on NTBs between the three countries indicates that these are now operating in most sectors, however, and their coverage in many sectors is large enough to imply serious distortions of prices and trade patterns. Price comparison data also support the view that North American tradeable prices are far more distorted than tariff levels alone would imply.

To test the real significance of tariff and nontariff distortions, a variety of liberalization scenarios were simulated with a CGE model of North America. These results indicate that each of the North American economies has much to gain from more liberal trade relations. The size of the potential gains depends primarily on two factors: the extent of real trade liberalization, and the extent to which the ensuing adjustment process realizes new economies of scale in production. Liberalization of tariffs alone would have a relatively minor effect, although some efficiency gains would accrue to all three countries. If a fuller liberalization were undcrtaken to include nontariff barriers, aggregate welfare gains might increase by more than tenfold in all three countries. Using estimates of unrealized scale economies for the three countries, we conclude that they have the potential to increase the gains from liberalization by another $50 \%$ or more.

\section{NOTES}

1. See ten Kate and de Mateo Venturini (1989) for a discussion of the Mexican case.

2. The RAS procedure is described in Stone and Brown (1965).

3. This appears to be symptomatic of the "endgame" process discussed by Lawrence (1990).

4. The subscripts $r, c, u$, and $m$ denote the Rest of the World, Canada, United States, and Mexico, respectively.

5. For Canada, the capital and labor components of value added came directly from the 1988 Canadian input-output accounts. Unfortunately, data availability is less current in the United States. Therefore, the value added data from Reinert and Roland-Holst (1992) are less precise than the Canadian data. However, the Reinert and Roland-Holst study made use of the most recent value added data available at the time.

6. Detailed explanations of these estimates and their sources are available from the authors.

7. The four-digit NTB classification and its concordance to the ten categories presented here are summarized in UNCTAD (1987).

8. For a discussion of these problems, see Laird and Yeats (1990), Pritchett (1991), and Roland-Holst (1992).

9. Dervis, de Melo, and Robinson (1982) give a general introduction to this methodology.

10. A complete specification of the model is available from the authors, as well as more detailed information about the database.

11. ROW import supply and export demand elasticities have been estimated by the authors for the United States. In every case, for the present sectoral aggregation and magnitude of trade adjustments, the small country assumption appears to be tenable. We extended this reasoning to both Canada and Mexico, and here the ROW price systems are essentially exogenous.

12. See de Melo and Tarr (1992) for details on these conventions. 
13. The main structural parameters are listed in the Appendix.

14. It is possible that harmonization of ROW protection would alter the results given here, but such policies are not presently under consideration.

15. The attribution of ad valorem distortions here is very approximate, but useful comparisons can be made if they are interpreted with care.

16. The adjustment in ROW exchange rates is dictated by the exchange rate arbitrage condition, so there is really only one ROW exchange rate. We experimented with other foreign closures, but the results did not change significantly.

17. In the present study, we have chosen not to specify an ad hoc foreign capital inflow process.

18. We also carried out tariff-only experiments under the increasing returns scenarios, but the results differed negligibly from Experiment 1 . As has already been observed, nominal North American tariffs are relatively low, and the output adjustments of this sector occasioned by their removal would be small.

19. In the case of imports, for example, the diversion measure is given by $d\left(m_{0}, m_{1}\right)=100 \| m_{1} /$ $\left|m_{0}\right|-m_{0}\|/\| m_{0} \| l$, where, for example, $m_{1}=\left(m_{\mathrm{ic}}, m_{\mathrm{im}}, m_{\mathrm{ir}}\right)$ denotes the 3-tuple of partner (e.g., U.S.) and ROW imports and II.II and I.I denote the Euclidean and simplex norms, respectively.

20. Complete sectoral results may be obtained from the authors. A few are cited here for illustrative purposes.

\section{REFERENCES}

Delorme, F., and J. Lester. 1990. "The Structure of Production in Ten Canadian Industries." Empirical Economics 15(4): 315-346.

Dervis, K., J. de Melo, and S. Robinson. 1982. General Equilibrium Models for Development Policy. Washington: The World Bank and Cambridge University Press.

Globerman, S., and M. Bader. 1991. "A Perspective of Trilateral Economic Relations." Pp. 153-174 in Continental Accord: North American Economic Integration, edited by S. Globerman. Vancouver: The Fraser Institute.

Harris, R.G. 1984. "Applied General Equilibrium Analysis of Small Open Economies and Imperfect Competition." American Economic Review 74(5): 1016-1032.

Kravis, Irving B., Alan Heston, and Robert Summers. 1982. World Product and Income: International Comparisons of Real Gross Product. Baltimore: Johns Hopkins University Press and the World Bank.

Laird, Samuel, and Alexander Yeats. 1990. Quantitative Methods for Trade-Barrier Analysis. New York: New York University Press.

Lawrence, R.Z. 1991. "Comment on Fung." Pp. 91-93 in Empirical Studies of Commercial Policy, edited by R.E. Baldwin. Chicago: University of Chicago Press.

Melo, J. de, and D. Tarr. 1992. A General Equilibrium Analysis of U.S. Foreign Trade Policy. Cambridge, MA: MIT Press.

Mexico. 1990. Segundo Informe de Gobierno, 1990 (Second Government Report). Mexico, D.F.

Morici, P. 1989. "The Canada-U.S. Free Trade Agreement." The International Trade Journal 3(4): 347-373.

Pritchett, L. 1991. "Measuring Outward Orientation in Developing Countries: Can it be Done?" Working Paper 566, The World Bank, Washington, DC.

Reinert, K.A., and D. Roland-Holst. 1992. "A Detailed Social Accounting Matrix for the United States." Journal of Economic Systems Research 4(2): 173-187.

Reinert, K.A., and D. Roland-Holst. 1991. "Parameter Estimates for U.S. Trade Policy Analysis." Unpublished manuscript, April.

Reinert, K.A., D. Roland-Holst, and C.R. Shiells. 1993. "Social Accounts and the Structure of the North American Economy." Economic Systems Research 5(3): 295-326 . 
Roland-Holst, D. 1992. "Estimates of Non-agricultural Trade Control Measures for Applied General Equilibrium Analysis." Report prepared for the International Economics Department, The World Bank, Washington, DC.

Sobarzo, H.E. 1991. "A General Equilibrium Analysis of the Gains from Trade for the Mexican Economy of a North American Free Trade Agreement." Working Paper No. II-91, Centro de Estudios Economicos, El Colegio de Mexico, August.

Statistics Canada. 1991a. Canada's Balance of International Payments. Ottawa, March.

Statistics Canada. $1991 \mathrm{~b}$. National Income and Expenditure Accounts. Ottawa, April.

Stone, R., and A. Brown. 1965. "Behavioural and Technical Change in Economic Models." Pp. 428-439 in Problems in Economic Development, edited by E.A.G. Robinson. London: Macmillan. ten Kate, Adriaan, and Fernando de Mateo Venturini. 1989. "Apertura comercial y estructura de la protección en México: Estimationes cuantitativas de los ochenta." Comercio Exterior 39(4): 312-329.

UNCTAD. 1987. Handbook of Trade Control Measures of Developing Countries. UNCTAD/DDM/Misc.2. Geneva: UNCTAD.

United States, Department of Commerce. 1988. Highlights of U.S. Export and Import Trade. FT 990, December. Washington, DC: U.S. GPO.

United States, Department of Commerce. 1991. Survey of Current Business. 71(6, June).

United States International Trade Commission. 1991. The Likely Impact on the United States of a Free Trade Agreement with Mexico. USITC Publication 2353, February. Washington, DC: U.S. GPO.

(Appendix follows on p. 168) 


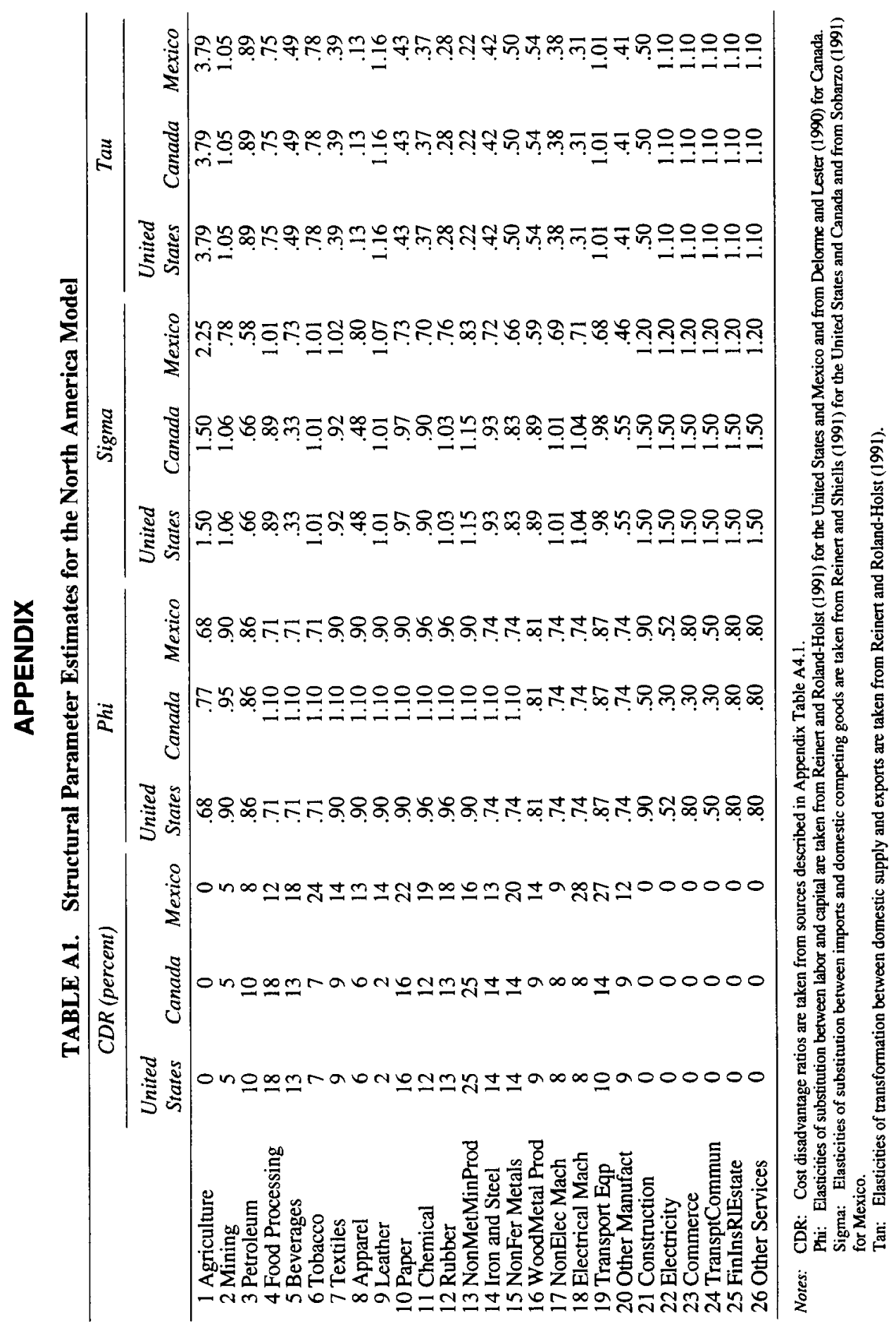

